\title{
ANALISIS IMPLEMENTASI INSTRUMEN TWO-TIER MULTIPLE CHOICE UNTUK MENGUKUR KETERAMPILAN PROSES SAINS
}

\section{AN ANALYSIS OF INSTRUMENT TWO-TIER MULTIPLE CHOICE IMPLEMENTATION FOR MEASURING SCIENCE PROCESS SKILL}

\author{
Dewi Ratnasari, Sukarmin, Suparmi \\ Universitas Sebelas Maret \\ Jalan Ir. Sutami 36 A Surakarta, Indonesia \\ e-mail: dewi_ratnasari@student.uns.ac.id, sukarmin67@staff.uns.ac.id, \\ suparmiuns@gmail.com
}

Naskah diterima tanggal: 11-8-2017, disetujui tanggal: 15-9-2017

\begin{abstract}
The research aimed to reveal the emergence percentage of Science Process Skill (SPS) indicator on summative test of $10^{\text {th }}$ grade in Surakarta in the academic year 2015/ 2016 and to find the capable alternative assessment instruments for measuring science process skill. This research was a descriptive research through the analysis of science process skill indicators on the summative test in Surakarta academic year of 2015/2016 and physics teacher questionnaire concerned teachers' instrument in physics learning process. Questionnaires were given to 67 Physics teachers in Surakarta and surrounding areas as samples using random sampling technique. The summative test was chosen from public and private senior secondary schools in Surakarta, representing high, medium and low-grade schools based on the average national examination score over the past 5 years. Selection of summative test sample using purposive sampling technique. The resuls show that the achievement percentage of Science Process Skill (SPS) indicators on the summative test of $10^{\text {th }}$ grade in Surakarta in the academic year 2015/2016 was dominated by the skill of applying concept and skill of planning experiment has the lowest percentage. The two-tier multiple-choice assessment instrument is one of capable alternative instruments to measuring students'science process skills. In conclusion, the low percentage of occurance of science process skill indicator in summative test requires alternative instrument to measure students' science process skill.
\end{abstract}

Keywords: assessment instrument, science process skill, summative test, two-tier multiple choice

Abstrak: Penelitian ini bertujuan untuk mengetahui persentase kemunculan indikator
Keterampilan Proses Sains (KPS) pada soal ulangan kenaikan kelas X pada SMA/MA di
Surakarta pada tahun ajaran 2015/2016 dan mengetahui instrumen penilaian alternatif
yang mampu untuk mengukur keterampilan proses sains siswa. Penelitian ini merupakan
penelitian deskriptif melalui analisis indikator keterampilan proses sains pada soal ulangan
kenaikan kelas pada SMA/MA di Surakarta tahun ajaran 2015/2016 dan melalui angket
tentang instrumen yang dipakai guru dalam proses pembelajaran Fisika. Angket diberikan
kepada 67 guru Fisika di Surakarta dan sekitarnya sebagai sampel dengan menggunakan
teknik random sampling. Soal ulangan kenaikan kelas dipilih dari SMA/MA di Surakarta baik
sekolah negeri maupun swasta yang mewakili sekolah kategori tinggi, sedang, dan rendah
berdasarkan rata-rata nilai UN selama 5 tahun terakhir. Pemilihan sampel soal ulangan
kenaikan kelas menggunakan teknik purposive sampling. Hasil penelitian menunjukkan
persentase kemunculan indikator KPS pada soal ulangan kenaikan kelas X di Surakarta
tahun ajaran 2015/2016 didominasi oleh keterampilan menerapkan konsep dan 
keterampilan merencanakan percobaan memiliki persentase kemunculan terendah. Selain itu, instrumen penilaian two-tier multiple choice merupakan salah satu instrumen alternatif yang mampu mengukur keterampilan proses sains siswa. Kesimpulan penelitian ini adalah masih rendahnya persentase kemunculan indikator keterampilan proses sains pada soal ulangan kenaikan kelas, sehingga diperlukan adanya alternatif instrumen yang mampu mengukur keterampilan proses sains siswa.

Kata Kunci: instrumen penilaian, keterampilan proses sains, soal ulangan kenaikan kelas, two-tier multiple choice.

\section{PENDAHULUAN}

Pendidikan menjadi bagian terpenting dalam kelangsungan hidup suatu bangsa. Undangundang Republik Indonesia nomor 20 tahun 2003 Bab II Pasal 3 tentang sistem pendidikan nasional menyatakan bahwa "pendidikan nasional berfungsi mengembangkan dan membentuk watak bangsa, sehingga pendidikan bertujuan untuk mengembangakan potensi peserta didik agar menjadi manusia yang beriman dan bertakwa kepada Tuhan Yang Maha Esa, berakhlak mulia, sehat, berilmu, cakap, kreatif, mandiri, dan menjadi warga Negara yang demokratis serta bertanggung jawab". Dengan demikian, ilmu pengetahuan dan kurikulum pengajaran harus dikembangkan untuk mendidik siswa yang cakap sehingga memiliki kemampuan memecahkan masalah. Melalui kurikulum 2013, guru diharapkan mampu menerapkan pembelajaran melalui pendekatan ilmiah (scientific approach) (Wardani, dkk., 2015).

Melalui penerapan pendekatan pembelajaran berbasis pendekatan ilmiah tersebut, pembelajaran harus mengembangkan beragam kemampuan seperti mengamati, bertanya, mengumpulkan informasi (bereksperimen), mengolah informasi (asosiasi), dan mengkomunikasikan (Sutjipto, 2016). Pendekatan berbasis ilmiah dalam pembelajaran IPA mampu melatih Keterampilan Proses Sains (KPS) siswa (Yamtinah, dkk., 2015).

Keterampilan proses sains (Science Process Skills) adalah keterampilan yang dapat membekali peserta didik untuk mampu melakukan berbagai kegiatan fisik selama proses penemuan (Hands on Activities) maupun keterampilan proses berpikir (Minds on Activities) dan menanamkan sikap ilmiah (Heart on Activities) (Erminingsing, dkk., 2013). Tujuan KPS tidak hanya melatih setiap siswa untuk menjadi seorang ilmuwan, tetapi juga membantu dan memfasilitasi mereka untuk berpikir seperti ilmuwan sehingga memahami topik-topik ilmiah (Yalçin, 2011). KPS akan membantu siswa menjadi pemecah masalah, sehingga siswa mampu menerapkan keterampilan ini dalam konteks dunia nyata (Monhardt \& Monhardt, 2006)

Keterampilan proses sains merupakan keterampilan berpikir siswa dengan menggunakan metode ilmiah sehingga siswa mampu untuk menemukan konsep atau pengetahuan. Metode ilmiah, pola pikir ilmiah dan berpikir kritis merupakan istilah dari keterampilan ini. Oleh karena itu, setidaknya selama dua dekade terakhir KPS menjadi lebih umum didengar (Özgelen, 2012).

Keterampilan proses sains (KPS) sangat penting untuk memahami pengetahuan dan telah menjadi tujuan penting dalam ilmu pendidikan. Melalui keterampilan ini, siswa akan tumbuh sebagai individu yang tidak hanya mampu mengakses informasi tetapi juga memahami informasi (Bati, dkk., 2010). KPS menurut Tawil \& Liliasari (2014) adalah aktivitas-aktivitas yang berkaitan dengan proses sains. Keterampilan proses ini digunakan oleh para ilmuwan ketika melakukan aktivitas sains karena sains terkait dengan aktivitas mengajukan pertanyaan, mencari jawaban dari pertanyaan yang diajukan, sehingga keterampilan ini harus diterapkan dalam kehidupan sehari-hari. Lebih lanjut Tawil 
dan liliasari (2014) mengungkapkan bahwa KPS bukan merupakan keterampilan tangan dalam penggunaan alat-alat tetapi merupakan keterampilan berpikir melalui proses-proses sains. Oleh karena itu, pokok ujinya pun dapat berupa tes tertulis sehingga diperlukan instrumen khusus untuk melengkapi pokok uji KPS tersebut. Hal tersebut sesuai dengan pernyataan Harlen (2013) yang menyatakan bahwa keterampilan proses sains tanpa disertai dengan penilaian akan menyebabkan proses pembelajaran yang dilakukan sia-sia. Oleh karena itu, diperlukan instrumen penilaian yang sesuai dengan keterampilan proses sains tersebut.

Bentuk instrumen two-tier multiple choice pertama kali dikembangkan oleh David Treagust (1988) dari Curtin University Australia. Instrumen two-tier multiple choice ini merupakan tes obyektif yang terdiri dari dua tingkat, tingkat pertama berupa soal utama (first-tier) dan tingkat kedua (second-tier) yang merupakan alasan pemilihan jawaban.

Menurut Treagust (1988), tes two-tier multiple choice dikembangkan dari butir pilihan ganda yang didesain sebanding dengan format pada 'Test of Logical Thinking' yang dikembangkan oleh Tobin \& Capie (1982). Bagian pertama dari setiap butir pada tes adalah pilihan ganda yang berisi pertanyaan dan umumnya terdiri dari beberapa pilihan jawaban. Bagian kedua pada setiap pertanyaan berisi sekelompok alasan yang mungkin dari pilihan jawaban yang diberikan pada bagian pertama.

Menurut Adodo (2013), two-tier multiple choice merupakan bentuk pertanyaan yang lebih rumit dibandingkan dengan bentuk pertanyaan pilihan ganda pada umumnya. Tingkat pertama (first-tier) menyerupai bentuk pertanyaan pilihan ganda tradisional (Multiple Choice Question/MCQ), dimana biasanya mengenai aspek pengetahuan. Tingkat kedua (secondtier) menyerupai format pada pertanyaan pilihan ganda tradisonal tetapi tujuannya untuk meningkatkan kemampuan tingkat tinggi dan kemampuan mengungkapkan alasan.
Teknik penskoran pada instrumen two-tier multiple choice menggunakan model penskoran Graded Response Model (GRM). GRM merupakan salah satu model yang dikembangkan untuk menangani skoring pada butir-butir soal politomus (De Ayala, 1993). Butir soal politomus merupakan butir soal yang memiliki respon jawaban lebih dari dua kemungkinan, sehingga guru lebih mudah melakukan koreksi jawaban siswa namun sekaligus dapat mendeteksi kemampuan siswa (Wardani, dkk., 2015)

Menurut Reckase (2009), pada model GRM, butir tes atau survei mengharuskan memiliki lebih dari dua kategori respon yang tergantung satu sama lain dan harus menyelesaikan satu langkah terlebih dahulu untuk kemudian menyelesaikan langkah berikutnya. Menurut Le (2013), model GRM tepat untuk butir dengan kategori respon yang berurutan atau bertingkat. Model ini memiliki pilihan respon termasuk kedalam respon bertingkat atau kategori tipe Likert seperti sangat tidak setuju, tidak setuju, netral, setuju, sangat setuju. GRM merupakan model analisis dari bentuk IRT (Item Response Theory) dimana respon siswa terhadap soal dapat menggambarkan suatu kemampuan tertentu. Model ini dikembangkan untuk mendeskripsikan hubungan antara karakteristik item dengan ciri atau sifat responden.

Pentingnya KPS dalam pembelajaran dan penilaian sains belum diterapkan maksimal oleh guru-guru di Indonesia. Hal ini dibuktikan oleh hasil penelitian Zamista \& Kaniawati (2015) yang menyatakan bahwa proses pembelajaran belum melatih KPS kepada siswa secara baik dan belum dilakukan penilaian khusus yang memuat indikator KPS. Kemampuan kognitif masih menjadi fokus penilaian guru sehingga penilaian KPS hanya pada saat kegiatan praktikum dan tanpa pedoman penilaian yang jelas. Salah satu penilaian yang dilakukan oleh guru adalah penilaian pada ulangan kenaikan kelas. Pada soal ulangan kenaikan kelas memuat materimateri yang telah diajarkan guru pada satu semester. Ulangan kenaikan kelas menjadi salah 
satu tolak ukur pemahaman siswa terhadap suatu materi. Namun, pengembangan soal ulangan kenaikan kelas umumnya hanya fokus pada aspek kognitif, tanpa mempertimbangkan kemampuan proses sains siswa sehingga konsep ini kurang tertanam pada siswa karena siswa hanya dituntut untuk hafal, bukan untuk berproses menggali informasi sendiri.

Tujuan dari penelitian ini yaitu: 1) mengetahui persentase kemunculan indikator Keterampilan Proses Sains (KPS) pada soal ulangan kenaikan kelas $X$ di Surakarta pada tahun ajaran 2015/2016 dan 2) mengetahui instrumen penilaian alternatif yang mampu untuk mengukur keterampilan proses sains siswa. Penelitian ini bermanfaat untuk mengetahui integrasi indikator KPS dalam tes sumatif (soal ulangan kenaikan kelas) yang dipakai oleh guru Fisika dan mengetahui instrumen penilaian pembelajaran yang dipakai oleh guru Fisika SMA/ MA di Surakarta dan sekitarnya serta mengetahui instrumen penilaian alternatif yang mampu mengukur KPS siswa.

\section{METODE}

Penelitian ini merupakan penelitian deskriptif. Desain penelitian deskriptif berusaha untuk menggambarkan apa, bagaimana, atau mengapa sesuatu terjadi. Pada penelitian deskriptif menggunakan sampel dari penyelidikan untuk mendokumentasikan, menggambarkan dan menjelaskan ada tidaknya pada fenomena yang diteliti (Ali, 2006)

Data dalam penelitian ini dikumpulkan melalui angket untuk guru Fisika SMA/MA yang terdiri dari 15 butir pertanyaan yaitu mengenai bentuk penilaian yang dipakai guru, hal yang dinilai guru saat pembelajaran Fisika, jenis instrumen penilaian yang digunakan, frekuensi penggunaan instrument pilihan ganda dan esai, kelemahan instrumen bentuk pilihan ganda, kelemahan instrumen bentuk esai, efektivitas instrument yang ada untuk mengukur KPS, alternatif instrumen yang mampu mengukur KPS, pendapat dan tanggapan mengenai instrumen two-tier multiple choice terkait dengan KPS.
Populasi pada penelitian ini adalah guru Fisika SMA/MA di Surakarta dan sekitarnya (Sukoharjo, Sragen, dan Wonogiri). Angket diberikan kepada 67 guru Fisika di Surakarta dan sekitarnya sebagai sampel dengan menggunakan teknik random sampling. Hasil data yang diperoleh akan dianalisis dengan cara deskriptif kualitatif yang meliputi reduksi data, penyajian data, serta penarikan kesimpulan. Tujuan angket ini adalah untuk mengetahui instrumen penilaian pembelajaran Fisika yang dipakai guru Fisika SMA/MA di Surakarta dan sekitarnya, penilaian keterampilan proses sains siswa (keterkaitan dan efektivitas instrumen yang ada dengan keterampilan proses sains), serta pengetahuan guru terhadap alternatif instrumen penilaian yang mampu mengukur keterampilan proses sains siswa.

Data juga diperoleh melalui analisis dokumen, yaitu analisis tes sumatif berupa soal ulangan kenaikan kelas (UKK) kelas X pada tahun ajaran 2015/2016 yang dipakai di beberapa sekolah di Surakarta. Teknik pemilihan sampel soal UKK kelas $\mathrm{X}$ menggunakan teknik purposive sampling. Soal ulangan kenaikan kelas dipilih dari sekolah negeri dan swasta yang mewakili kategori tinggi, sedang dan rendah berdasarkan nilai UN dalam lima tahun terakhir.

Teknik pengumpulan data menggunakan lembar checklist yang telah disusun berdasarkan indikator keterampilan proses sains. Indikator keterampilan proses sains yang digunakan dalam penelitian ini terdiri dari dua level KPS yakni KPS dasar dan KPS terintegrasi. Indikatorindikator KPS tersebut meliputi keterampilan menyusun hipotesis, keterampilan merencanakan percobaan, keterampilan menganalisis data, keterampilan menerapkan konsep, keterampilan mengkomunikasikan, dan keterampilan menarik kesimpulan.

Soal ulangan kenaikan kelas dari enam sekolah baik negeri maupun swasta di Surakarta dianalisis berdasarkan indikator keterampilan proses sains. Banyaknya kemunculan setiap indikator ditabulasikan dan dihitung rata-rata kemunculan pada setiap indikator. Pemilihan 
indikator keterampilan proses sains tersebut juga didasarkan pada karakteristik kurikulum 2013 yang dipakai di Indonesia yakni dengan menggunakan pendekatan saintifik (scientific approach).

Hasil angket yang diberikan kepada guruguru Fisika SMA/MA di Surakarta dan sekitarnya memberikan gambaran instrumen penilaian yang dipakai guru dalam pembelajaran Fisika, penilaian keterampilan proses sains siswa (keterkaitan dan efektivitas instrumen dengan KPS), serta pengetahuan guru terhadap alternatif instrumen yang mampu mengukur KPS siswa salah satunya melalui instrumen penilaian two-tier multiple choice. Berdasarkan data dari angket guru Fisika SMA/MA di Surakarta dan berdasarkan ratarata kemunculan indikator keterampilan proses sains pada soal ulangan kenaikan kelas, dapat dianalisis bentuk penilaian yang dipakai guru dalam pembelajaran Fisika serta bagaimana soal ulangan kenaikan kelas di Surakarta dikembangkan.

\section{HASIL DAN PEMBAHASAN}

Angket yang telah diberikan kepada 67 guru Fisika SMA/MA di Surakarta dan sekitarnya kemudian direkap dan dianalisis pada setiap butir pertanyaan. Hasil analisis angket guru tersebut disajikan dalam Tabel 1.

Berdasarkan Tabel 1, dapat diketahui bahwa instrumen penilaian yang dipakai oleh guru Fisika adalah instrumen bentuk tes dengan persentase sebesar 97,01\%. Aspek utama yang menjadi penilaian guru Fisika SMA/MA di Surakarta dan sekitarnya yaitu aspek pengetahuan (94,03\%), sedangkan aspek sikap dan aspek keterampilan persentasenya berada di bawah aspek pengetahuan. Hal ini menunjukkan bahwa aspek kognitif masih menjadi bagian pokok dalam evaluasi yang digunakan guru daalm proses pembelajaran Fisika.

Implementasi kurikulum 2013 mengharuskan guru mampu memberikan penilaian terhadap pengetahuan, sikap, dan keterampilan sekaligus. Ketiga aspek tersebut menjadi satu kesatuan dalam sistem evaluasi pada kurikulum 2013.
Dengan demikian, proses penilaian pada kurikulum 2013 tidak hanya terfokus pada aspek kognitif saja.

Dalam melakukan penilaian, umumnya guru menggunakan instrumen dalam bentuk esai. Walaupun terdapat beberapa kelemahan, instrumen ini tetap dipakai hampir setiap kali melakukan penilaian. Beberapa kelemahan soal esai berdasarkan pendapat guru yaitu cakupan materi kurang luas, waktu koreksi lebih lama, sulit dalam menentukan skor, rubrik penilaian harus rinci karena terkadang jawaban siswa terlalu melebar dari pertanyaan, dan terkadang penilaian bisa bersifat subjektif.

Selain instrumen bentuk esai, pilihan ganda dan jawaban singkat, jenis instrumen yang dikenal oleh guru sudah cukup banyak dan beragam. Namun, berdasarkan hasil pada Tabel 1 , sebagian besar guru belum mengaitkan soalsoal yang diberikan kepada siswa dengan keterampilan proses sains.

KPS tidak hanya mampu mendorong siswa untuk menemukan konsep, tetapi juga mampu mendorong siswa untuk berpikir kritis. Keterampilan proses sains sangat penting untuk pembelajaran yang bermakna karena akan terus berlanjut dalam kehidupan sehari-hari siswa (Ratnasari, dkk., 2017) Melalui KPS, siswa akan menggunakan pikirannya untuk menerapkan berbagai konsep atau prinsip. Dalam proses penemuan (discovery), siswa melakukan berbagai aktivitas seperti mengamati, mengukur, memprediksi, menganalisis dan menyimpulkan. Dengan demikian, siswa mampu membentuk konsep dasar (prior knowledge) didalam pikirannya. Melalui proses ini, konsep menjadi lebih tertanam dan tidak sekedar hafalan (Yulia, dkk., 2016).

KPS cukup penting ini dalam proses pembelajaran sehingga diperlukan instrumen yang mampu mengukur keterampilan proses sains. Hal ini sesuai dengan pendapat guru, yakni $92,54 \%$ guru menyatakan perlu adanya instrumen alternatif yang mampu mengukur KPS karena instrumen yang ada (pilihan ganda, esai dan jawaban singkat) belum cukup efektif untuk 
mengukur KPS. Berdasarkan kelemahan instrumen pilihan ganda dan esai yang diungkapkan oleh guru, instrumen alternatif yang digunakan untuk mengukur KPS diharapkan mampu mengatasi kelemahan instrumen yang ada. Pengembangan keterampilan proses sains sangat cocok diterapkan pada siswa karena melalui KPS siswa mampu menyelesaikan masalah, berpikir kritis, memutuskan, dan menemukan jawaban dari hipotesis sehingga siswa lebih mampu mengingat konsep yang diperoleh (Germann \& Aram, 1996).

Two-tier multiple choice merupakan instrumen tes dua tingkat yang mampu mengatasi kelemahan instrumen pilihan ganda dalam hal kecenderungan siswa yang hanya menebak. Selain mampu mengatasi kelemahan soal esai dan pilihan ganda, soal bentuk two-tier multiple choice juga dapat digunakan untuk mengukur keterampilan proses sains siswa. Hal ini senada dengan hasil penelitian Wulandari, dkk. (2015) menyatakan bahwa instrumen penilaian twotier multiple choice mampu mengukur keterampilan proses sains. Selain itu, melalui instrumen tersebut diperoleh profil KPS siswa dan profil pemahaman konsep siswa, sehingga guru mampu menentukan tindak lanjut yang merupakan sarana yang informatif untuk mengetahui pemahaman siswa serta mengetahui keterampilan proses sains yang dimiliki siswa.

Instrumen alternatif lain yang mampu untuk mengukur keterampilan proses sains adalah instrumen pilihan ganda dan uraian. Namun, kedua instrumen memiliki beberapa kelemahan. Instrumen pilihan ganda biasa tidak dapat menanggulangi kecenderungan guessing siswa, bahkan blind guessing oleh siswa tanpa membaca soal dan opsi jawaban, sedangkan soal uraian (essay) memiliki kelemahan dalam hal subyektivitas penilaian dan waktu koreksi (Yamtinah, dkk., 2015)

Melalui metode skoring dengan Graded Respon Model (GRM), kelemahan instrumen essay dalam hal waktu koreksi dapat diminimalisasi dan kelemahan soal pilihan ganda dalam hal menggali penguasaan konsep siswa juga mampu dihindari.
Melalui metode GRM ini, respon siswa terhadap butir siswa cenderung meningkat. Artinya, pada instrumen ini memiliki dua kategori respon yang tergantung satu sama lain dan harus menyelesaikan satu langkah terlebih dahulu untuk kemudian menyelesaikan langkah berikutnya.

Menurut Yamtinah, dkk. (2016), penerapan Graded Response Model (GRM) tersebut diaplikasikan pada penskoran instrumen penilaian two-tier multiple choice dengan pedoman penskoran yang disajikan dalam Tabel 2 .

Tabel 2 Skoring pada Soal Two-tier Multiple Choice

\begin{tabular}{cll}
\hline No & Kriteria Penilaian & Skor \\
\hline 1 & $\begin{array}{l}\text { Tidak memilih jawaban } \\
\text { dan alasan, atau jawaban } \\
\text { salah-alasan salah }\end{array}$ & 0 \\
2 & $\begin{array}{l}\text { Jawaban salah-alasan } \\
\text { benar (SB) }\end{array}$ & 1 \\
3 & $\begin{array}{l}\text { Jawaban benar-alasan } \\
\text { salah (BS) }\end{array}$ & 2 \\
4 & $\begin{array}{l}\text { Jawaban benar-alasan } \\
\text { benar (BB) }\end{array}$ & 3 \\
\hline
\end{tabular}

Sumber: Yamtinah, dkk., 2016

Berdasarkan angket yang diberikan terhadap 67 guru Fisika di daerah Surakarta dan sekitarnya, hampir semua guru memberikan respon yang positif terhadap instrumen two-tier multiple choice untuk mengukur keterampilan proses sains. Menurut para guru, instrumen twotier multiple choice dapat mencegah siswa yang hanya menebak jawaban, siswa dapat berpikir secara kritis, sistematis, dan analitis. Selain itu, instrumen bentuk ini juga mampu mengukur pemahaman siswa secara lebih mendalam bukan sekedar menghafal.

Hasil analisis angket guru pada Tabel 1, $58,21 \%$ guru telah mengaitkan soal-soal yang diberikan dengan keterampilan proses sains. Namun, 52,24\% guru menyatakan instrumen yang telah ada belum efektif mengukur keterampilan proses sains siswa. Penilaian yang dilakukan oleh guru salah satunya adalah penilaian pada ulangan kenaikan kelas. Pada soal ulangan kenaikan kelas memuat materi-materi yang telah diajarkan guru pada satu semester. Ulangan 
kenaikan kelas menjadi salah satu tolak ukur pemahaman siswa terhadap suatu materi. Namun, pengembangan soal ulangan kenaikan kelas umumnya hanya fokus pada aspek kognitif, tanpa mempertimbangkan kemampuan proses sains siswa. Hal tersebut menyebabkan konsep kurang tertanam pada siswa karena siswa hanya dituntut untuk hafal, bukan untuk berproses menggali informasi sendiri. Hasil analisis soal ulangan kenaikan kelas yang digunakan di Surakarta dapat dilihat pada Tabel 3.
Berdasarkan analisis soal ulangan kenaikan kelas yang disajikan dalam Tabel 3 dapat diketahui bahwa penilaian yang digunakan guru hanya terfokus pada aspek kognitif yakni menerapkan konsep. Sedangkan keterampilan merancang percobaan menjadi keterampilan yang memiliki persentase kemunculan paling sedikit pada soal ulangan kenaikan kelas. Untuk memperjelas persentase setiap indikator KPS pada soal ulangan kenaikan kelas (UKK) pada setiap sekolah dapat dilihat pada Gambar 1.

Tabel 3 Hasil Analisis Keterampilan Proses Sains Pada Setiap Soal Ulangan Kenaikan Kelas

\begin{tabular}{lccccccc}
\hline \multicolumn{1}{c}{ Indikator KPS } & $\begin{array}{c}\text { UKK A } \\
(\%)\end{array}$ & $\begin{array}{c}\text { UKK B } \\
(\%)\end{array}$ & $\begin{array}{c}\text { UKK C } \\
(\%)\end{array}$ & $\begin{array}{c}\text { UKK D } \\
(\%)\end{array}$ & $\begin{array}{c}\text { UKK E } \\
(\%)\end{array}$ & $\begin{array}{c}\text { UKK F } \\
(\%)\end{array}$ & $\begin{array}{c}\text { Rata- } \\
\text { rata }\end{array}$ \\
\hline Menyusun hipotesis & 0 & 4,44 & 2,86 & 0 & 0 & 10 & 2,88 \\
Merencanakan percobaan & 2,5 & 2,22 & 2,86 & 5 & 0 & 0 & 2,10 \\
Menganalisis data & 2,5 & 2,22 & 14,29 & 2,5 & 5,71 & 3,33 & 5,10 \\
Menerapkan konsep & 82,5 & 53,33 & 74,29 & 72,5 & 68,58 & 70 & 70,20 \\
Mengkomunikasikan & 5 & 13,33 & 0 & 12,5 & 5,71 & 3,33 & 6,64 \\
Menarik kesimpulan & 7,5 & 24,44 & 5,71 & 7,5 & 20 & 13,33 & 13,08 \\
\hline
\end{tabular}

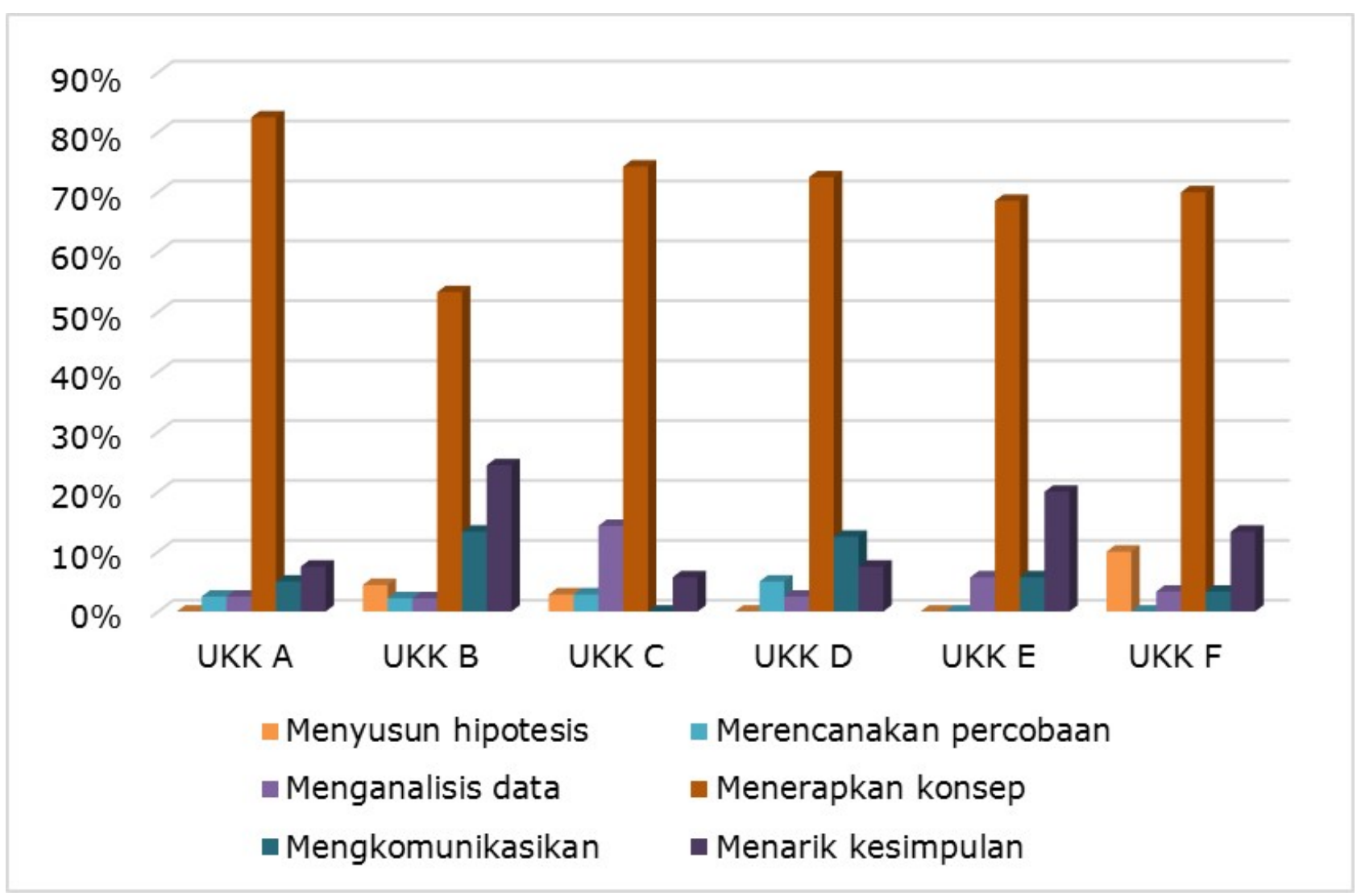

Gambar 1 Grafik Persentase Indikator KPS pada Setiap Soal UKK 
UKK A sampai UKK F menyatakan soal ulangan kenaikan kelas yang diperoleh dari 6 sekolah di Surakarta yang mewakili kategori tinggi, sedang, dan rendah dari sekolah SMA/ MA negeri maupun swasta. Berdasarkan data rata-rata kemunculan indikator KPS pada setiap soal UKK, indikator yang paling besar persentase kemunculan adalah indikator menerapkan konsep, sedangkan indikator yang paling kecil persentase kemunculannya adalah indikator merencanakan percobaan.

Dari Grafik 1, terlihat jelas selisih perbedaan yang sangat signifikan antara keterampilan menerapkan konsep dengan keterampilanketerampilan lainnya. Keterampilan menerapkan konsep menjadi keterampilan yang selalu dominan di setiap soal ulangan kenaikan kelas di setiap sekolah yang menjadi sampel penelitian.

Dominasi keterampilan tertentu pada soal ulangan kenaikan kelas menunjukkan bahwa soal belum secara maksimal mengukur keterampilan proses sains siswa. Bahkan pada Tabel 3 dan Gambar 1, terdapat keterampilan tertentu yang persentase kemunculannya $0 \%$.

Keterampilan yang paling rendah rata-rata kemunculannya adalah keterampilan merencanakan percobaan. Hal ini senada dengan hasil penelitian Subali (2015) yang menunjukkan bahwa pada bagian yang tersukar dalam keterampilan proses sains adalah merancang investigasi (merancang percobaan).

Keterampilan merencanakan percobaan seharusnya menjadi keterampilan yang wajib diberikan kepada siswa. Akani, (2015) menyatakan bahwa merencanakan percobaan dan observasi menjadi aktivitas kunci dalam belajar sains, sehingga hal ini menjadi komponen penting dalam belajar mengajar dan menerapkan sains. Germann (1994) mengungkapkan bahwa tujuan utama dari pembelajaran sains adalah membantu siswa untuk mengkonstruksi pengetahuan yang berpusat pada fenomena sains, dan dalam waktu bersamaan, membantu siswa untuk mengungkapkan alasan, berpikir kritis dan menyelesaikan masalah. Salah satu cara mencapai tujuan pembelajaran sains adalah melalui pembelajaran berbasis inkuiri di laboratorium yang menekankan keterampilan proses sains dasar dan keterampilan proses sains terintegrasi.

Pentingnya keterampilan merencanakan percobaan ini juga diungkapkan oleh Duruk, dkk. (2017) yang menyatakan bahwa pembelajaran berbasis penemuan akan membuat siswa menggunakan keterampilan berpikir tingkat tinggi untuk menarik kesimpulan berdasarkan bukti-bukti. Pada proses merencanakan percobaan ini siswa menggunakan beberapa keterampilan proses sains lainnya seperti mengumpulkan data, mengindentifikasi variabel, menyusun hipotesis dan lain-lain. Secara bersamaan, keterampilan merencanakan percobaan ini menjadi keterampilan proses sains yang penting karena menggabungkan banyak keterampilan untuk menganalisis secara lebih mendalam selama melakukan percobaan yang berulang-ulang.

Selain indikator merencanakan percobaan, indikator KPS lainnya yang memiliki persentase kemunculan rendah adalah indikator menyusun hipotesis. Duruk, dkk. (2017) menyatakan bahwa hipotesis merupakan data berdasarkan tebakan yang berasal dari pengetahuan sebelumnya dan pengamatan berulang. Hipotesis juga dapat disebut sebagai penjelasan yang disimpulkan dari pengamatan. Keterampilan menyusun hipotesis menjadi salah satu keterampilan yang jarang muncul pada soal. Hal ini harus menjadi perhatian tersendiri karena keterampilan menyusun hipotesis menjadi salah satu kompenen penting dalam pembelajaran sains. Hal ini senada dengan Kuhn \& Dean (2005) yang menyatakan bahwa keterampilan menyusun hipotesis menjadi komponen penting dalam saintifik dan inkuiri karena untuk memahami sains, sangat penting bagi siswa untuk mencari informasi yang berawal dari pengajuan hipotesis sehingga siswa akan berusaha mencari tahu jawaban dari hipotesis.

Menurut Sukarno, dkk. (2013), rendahnya persentase kemunculan indikator KPS dalam soal 
salah satunya dikarenakan penilaian uji kompetensi siswa selama ini hanya terfokus pada penguasaan konsep-konsep saja. Selain itu, guru juga kurang paham bagaimana mengembangkan instrumen yang mampu mengukur keterampilan proses sains siswa. Lebih lanjut Sukarno, dkk. (2013) menyatakan bahwa salah satu cara menanggulangi hal tersebut yaitu dengan cara memberikan pelatihan kepada guru-guru sains mengenai keterampilan proses sains. Pelatihan tersebut terdiri dari pengetahuan tentang KPS, indikator-indikator KPS, dan penilaian KPS. Melalui pelatihan tersebut diharapkan guru mampu menerapkan pengetahuannya dalam mengembangkan KPS pada siswa.

Pengembangan instrumen yang mampu mengukur keterampilan proses sains sangat diperlukan guru karena saat ini KPS menjadi komponen yang penting dalam pembelajaran sains. Hal tersebut senada dengan Karamustafaoðlu (2011) yang menyatakan bahwa penerapan KPS sangat krusial pada pembelajaran bermakna sebab belajar melalui kehidupan sehari-hari dan siswa perlu untuk menemukan, menginterpretasi, dan mempertimbangkan fakta-fakta melalui kondisi-kondisi yang mereka hadapi. Hal serupa diungkapkan oleh Subali \& Mariyam (2013) berdasarkan hasil survei terhadap 400 guru dan 1200 grup siswa dari 10 UPT pada 5 kabupaten/kota di DIY yang menunjukkan bahwa hampir semua guru menyatakan pentingnya pembelajaran untuk mengembangkan kreativitas keterampilan proses sains dalam aspek kehidupan kepada peserta didik.

Keterampilan proses sains telah menjadi bagian penting dalam pembelajaran sains (termasuk Fisika). Melalui keterampilan proses sains, siswa dapat menemukan konsep, bukan sekedar menghafal konsep. Menurut Carey, $d k k$. (1989), keterampilan proses sains merupakan keterampilan khusus yang menyederhanakan pembelajaran sains, mengaktifkan siswa, mengembangkan kepekaan siswa terhadap pembelajaran, membuat konsep yang dipelajari menjadi lebih permanen dengan mengajari mereka metode ilmiah.
Keterampilan proses sains telah menjadi komponen yang utama dalam studi literatur pembelajaran sains sejak kurikulum utama pertama kali dimulai tahun 1960-an. Menurut American Association for the Advancement of Science (1967) keterampilan proses sains dibagi menjadi dua level yaitu keterampilan proses sains dasar dan keterampilan proses sains terintegrasi. Keterampilan proses dasar meliputi keterampilan mengamati, mengklasifikasi, mengomunikasikan, mengukur, menggunakan hubungan ruang dan waktu, menggunakan angka-angka, menginferensi, dan memprediksi. Keterampilan proses terintegrasi meliputi keterampilan mengontrol variabel, menginterpretasi data, merumuskan hipotesis, mendefinisikan secara operasional, dan melakukan percobaan.

Menurut Depdiknas (2013), Keterampilan proses sains dasar meliputi keterampilan mengamati, menggolongkan atau mengklasifikasi, mengukur, mengkomunikasikan, menginterpretasi data, memprediksi, menggunakan alat, melakukan percobaan dan menyimpulkan. Sedangkan keterampilan proses sains terintegrasi meliputi keterampilan merumuskan masalah, mengidentifikasi variabel, mendeskripsikan hubungan antarvariabel, mengontrol variabel, mendefinisikan variabel secara operasional, memperoleh dan menyajikan data, mengajukan hipotesis, merancang penelitian dan melakukan penyelidikan dan percobaan.

Keterampilan proses sains juga memiliki dampak positif terhadap prestasi belajar siswa. Penelitian-penelitian terdahulu menunjukkan adanya korelasi positif antara prestasi akademik dan KPS (Beaumont-Walters \& Soyibo (2001); Sinan \& Usak (2011); Delen \& Kesercioglu, (2012)). KPS dan prestasi akademik saling berkaitan untuk proses perubahan konseptual siswa. Sehingga untuk mengembangkan perubahan konseptual tingkat tinggi diperlukan keterampilan proses sains ini, karena KPS tidak dapat dipisahkan dengan perubahan konseptual dan pemahaman konseptual (Karamustafaoðlu, 2011). KPS dapat dilihat sebagai faktor yang 
mendukung pemahaman konsep karena berkorelasi dengan prestasi akademik.

Instrumen two-tier multiple choice menjadi instrumen alternatif yang mampu digunakan untuk mengukur keterampilan proses sains siswa. Selain mampu mengukur KPS, instrumen two-tier multiple choice juga mampu untuk mengukur taraf berpikir siswa. Hal serupa dengan yang diungkapkan oleh Adodo (2013) yang menyatakan bahwa two-tier multiple choice merupakan model penilaian yang terbukti sangat bermanfaat bagi pendidikan dan juga dapat membantu siswa tidak hanya memahami materi pembelajaran, tetapi dapat mengukur keterampilan berpikir tingkat tinggi siswa, selain itu mampu membantu guru mengidentifikasi miskonsepsi pada siswa.

Kelebihan instrumen two-tier multiple choice menurut Zeilik, dkk. (1997) yaitu guru dapat menggunakan instrumen ini untuk fungsi formatif dan sumatif pada akhir semester. Jika guru ingin menggunakan sebagai tes formatif, guru harus mengetahui kemampuan kognitif siswa, konsep awal siswa, dan miskonsepsi siswa. Jika guru ingin menggunakan sebagai tes sumatif, guru dapat melihat pengaruh positif atau negatif dari pembelajaran yang telah dilakukan, sehingga mampu memberikan umpan balik terhadap proses pembelajaran. Sebab tujuan utama dari penilaian adalah "diagnosis" bukan prestasi siswa.

Berdasarkan kelebihan tersebut, instrumen two-tier multiple choice mampu diterapkan saat ulangan harian, ujian tengah semester atau saat ulangan kenaikan kelas. Sehingga pembelajaran fisika menjadi pelajaran yang bermakna karena fisika bukan hanya sekedar menghafal konsep, tetapi mampu untuk menemukan konsep.

\section{SIMPULAN DAN SARAN}

\section{Simpulan}

Persentase kemunculan indikator Keterampilan Proses Sains (KPS) pada soal ulangan kenaikan kelas X di Surakarta tahun ajaran 2015/2016 didominasi oleh keterampilan menerapkan konsep. Sementara itu, keterampilan merencanakan percobaan memiliki persentase kemunculan terendah. Kemunculan indikator KPS dalam soal ulangan kenaikan kelas masih rendah sehingga diperlukan alternatif instrumen yang mampu mengukur KPS siswa. Instrumen penilaian two-tier multiple choice merupakan salah satu instrumen alternatif yang mampu mengukur keterampilan proses sains siswa.

\section{Saran}

Rendahnya persentase kemunculan indikator KPS pada soal ulangan kenaikan kelas salah satunya disebabkan oleh bahan ajar seperti buku ajar yang digunakan belum terintegrasi dengan indikator KPS. Oleh karena itu, diharapkan pemerintah daerah melalui dinas pendidikan mampu menyediakan bahan ajar yang mendorong berkembangnya keterampilan proses sains siswa. Selain itu, pemerintah daerah dan dinas pendidikan diharapkan mampu memberikan pelatihan (training) agar guru mengetahui pengembangan bahan ajar yang terintegrasi dengan KPS dan instrumen yang mampu mengevaluasi hasil belajar siswa secara umum maupun mengevaluasi keterampilan proses sains, salah satunya instrumen two-tier multiple choice. Selain melalui kegiatan pelatihan (training), dinas pendidikan diharapkan lebih mengaktifkan kembali Kelompok Kerja Guru (KKG) dan kegiatan Musyawarah Guru Mata Pelajaran (MGMP), sebagai media guru untuk belajar dan bertukar informasi tentang pengembangan bahan ajar dan instrumen yang terintegrasi KPS, indikator dalam KPS serta karakteristik KPS dalam pembelajaran sains, terutama dalam pembelajaran fisika. 


\section{PUSTAKA ACUAN}

American Association for the Advancement of Science. 1967. Science-A Process Approach. Washington, D.C: American Association for the Advancement of Science.

Adodo, S. O. 2013. Effects of Two-Tier Multiple Choice Diagnostic Assessment Items on Students' Learning Outcome in Basic Science Technology (BST). Academic Journal of Interdisciplinary Studies, 2(2),201-210. doi:org/10.5901/ajis.2013.v2n2p201

Akani, O. 2015. Levels of Possession of Science Process Skills by Final Year Students of Colleges of Education in South-Eastern States of Nigeria. Journal of Education and Practice, 6(27), 94-102.

Ali, A. 2006. Conducting research in education and the social sciences. Enugu: Tashiwa Net Woness Ltd.

Bati, K., Ertürk, G., \& Kaptan, F. 2010. The Awareness Levels of Pre-school Education Teachers Regarding Science Process Skills. Procedia - Social and Behavioral Sciences, 2(2),19931999, doi:10.1016/j.sbspro.2010.03.270

Beaumont-Walters, Y., \& Soyibo, K. 2001. An Analysis of High School Students' Performance on Five Integrated Science Process Skills. Research in Science \& Technological Education, 19(2),133-145. doi:10.1080/02635140120087687

Carey, S., Evans, R., Honda, M., Jay, E., \& Unger, C. 1989. An Experiment is When You Try It and See If It works: A Study of Grade 7 Students' Understanding of the Construction of Scientific Knowledge. International Journal of Science Education, 11(5),514-529. https:// doi.org/10.1080/0950069890110504

De Ayala, R. J. 1993. An Introduction to Polytomous Item Response Theory Models. Measurement \& Evaluation in Counseling \& Development 25(4),172-189.

Delen, I., \&, Kesercioglu, T. 2012. How Middle School Students' Science Process Skills Affected by Turkey's National Curriculum Change? Journal of Turkish Science Education, 9(4),3-9.

Depdiknas. 2013. Materi Pelatihan Guru Implementasi Kurikulum 2013 SMP/MTs IImu Pengetahuan Alam. Jakarta: Kemendikbud.

Duruk, U., Akgün, A., Doðan, C., \& Gülsuyu, F. 2017. Examining the Learning Outcomes Included in the Turkish Science Curriculum in Terms of Science Process Skills: A Document Analysis with Standards-Based Assessment. International Journal Of Environmental and Science Education, 12(2),117-142.

Ermaningsih, Sudarisman S., Suparmi. 2013. Pembelajaran Biologi Model PBM Menggunakan Lembar Kerja Terbimbing dan Lembar Kerja Bebas Termodifikasi Ditinjau dari Keterampilan Proses Sains dan Kemampuan Berpikir Analitis. Jurnal Inkuiri, 2(2),132-142.

Germann, P. J. 1994. Testing a Model of Science Process Skills Acquisition: an Interaction with Parents' Education, Preferred Language, Gender, Science Attitude, Cognitive Development, Academic Ability, and Biology Knowledge. Journal of Research in Science Teaching, 31(7),749-783. https://doi.org/10.1002/tea.3660310707

Germann, P. J., \& Aram, R. J. 1996. Student Performances on the Science Processes of Recording Data, Analyzing Data, Drawing Conclusions, and Providing Evidence. Journal of Research in Science Teaching, 33(7),773-798. https://doi.org/10.1002/(SICI)10982736(199609)33

Harlen, W. 2013. Inquiry-Based Learning in Science and Mathematics. Review of Science 
Mathematics \& ICT Education, 7(2),9-33.

Karamustafaoðlu, S. 2011. Improving the Science Process Skills Ability of Science Student Teachers. Eurasian Journal of Physics and Chemistry Education, 3(1),26-38.

Kuhn, D., \& Dean, D. 2005. Is Developing Scientific Thinking All About Learning to Control Variables? Psychological Science. A Journal of the American Psychological Society/APS, 16(11), 866-870. https://doi.org/10.1111/j.1467-9280.2005.01628.x

Le, D.-T. 2013. Applying Item Response Theory Modeling in Educational Research. Graduate Theses and Dissertations, Paper 1341. Iowa: Iowa State University

Monhardt, L., \& Monhardt, R. 2006. Creating a Context for the Learning of Science Process Skills through Picture Books. Early Childhood Education Journal, 34(1),67-71. https://doi.org/ 10.1007/s10643-006-0108-9

Ratnasari, D., S Sukarmin, S Suparmi \& N S Aminah. 2017. Students' Conception on Heat and Temperature toward Science Process Skill. IOP Conf. Series: Journal of Physics: Conf. Series 895 (2017) 012044. doi:10.1088/1742-6596/895/1/012044.

Sinan, O. \& Usak, M. 2011. Evaluating of Prospective Biology Teachers Scientific Process Skills. Mustafa Kemal University Journal of Social Sciences Institute, 8(15),333-348.

Özgelen, S. 2012. Students' Science Process Skills within a Cognitive Domain Framework. Eurasia Journal of Mathematics Science \& Technology Education, 8(4),283-292. https:// doi.org/10.12973/eurasia.2012.846a.

Reckase, M. D. 2009. Multidimensional Item Response Theory. Multidimensional Item Response Theory. https://doi.org/10.1007/978-0-387-89976-3.

Subali, B. 2015. Pengukuran Kreativitas Keterampilan Proses Sains Dalam Konteks Assessment for Learning. Jurnal Cakrawala Pendidikan, 1(1),130-144.

Subali, B. dan Mariyam, S. 2013. Pengembangan Kreativitas Keterampilan Proses Sains Dalam Aspek Kehidupan Organisme Pada Mata Pelajaran IPA SD. Cakrawala Pendidikan, 32(3), 365-381.

Sukarno, Permanasari, A., \& Hamidah, I. 2013. The Profile of Science Process Skill (SPS) Student at Secondary High School (Case Study in Jambi). International Journal of Scientific Engineering and Research (IJSER), 1(1),79-83.

Sutjipto. 2016. the Importance of Training Curriculum 2013 for Teachers Pentingnya Pelatihan Kurikulum 2013 Bagi Guru. Jurnal Pendidikan Dan Kebudayaan, 1(2),235-260.

Tobin, K. G., \& Capie, W. 1982. Relationships between Formal Reasoning Ability, Locus of Control, Academic Engagement and Integrated Process Skill Achievement. Journal of Research in Science Teaching, 19(2),113-121. https://doi.org/10.1002/tea.3660190203

Treagust, D. F. 1988. Development and Use of Diagnostic Tests to Evaluate Students' Misconceptions in Science. International Journal of Science Education, 10(2),159-169. https://doi.org/10.1080/0950069880100204

Wardani, R. K., Yamtinah, S., \& Mulyani, B. 2015. Instrumen Penilaian Two-Tier Test Aspek Pengetahuan Untuk Mengukur Keterampilan Proses Sains (KPS) Pada Pembelajaran Kimia Untuk Siswa SMA/MA Kelas X, 4(4),156-162.

Yalçin, F. A. 2011. The Evaluation of the Unit "Structure and Properties of Matter" in Primary 8th Grade Science and Technology Teacher Guide Book With Regard to Scientific Process Skills. Elementary Education Online, 10(1),378-388. 
Yamtinah, S., Haryono, Saputro, S., Mulyani, B., \& BU, S. 2016. Item Discrimination of Two Tier Test. Proceeding International Conference on Educatonal Research and Evaluating (ICERE). 29-31 May 2016, Yogyakarta State University.

Yamtinah, S., Saputro, S., \& Haryono. 2015. Instrumen Alternatif untuk Penilaian Ketrampilan Proses Sains (KPS) dan Berfungsi Diagnostik pada Aspek Pengetahuan. Jurnal Materi dan Pembelajaran Fisika (JMPF) 5(2),33-40.

Yulia, L. D., Sunarno, W., \& Aminah N.S. 2016. Pengembangan Modul Fisika Berbasis Keterampilan Proses Sains (KPS) untuk Meningkatkan Kemampuan Pemecahan Masalah Fisika Siswa pada Materi Kalor di SMA/MA. Tesis, Pascasarjana UNS, Surakarta. Tidak dipublikasikan.

Zamista, A. A., \& Kaniawati, I. 2015. Pengembangan Tes Keterampilan Proses Sains Materi Fluida Statis Kelas X SMA / MA. Seminar Nasional Fisika (SNF) IV. IV, 5-10.

Zeilik, M., Schau, C., Mattern, N., Hall, S., Teague, K. W., \& Bisard, W. 1997. Conceptual Astronomy: A Novel Model for Teaching Postsecondary Science Courses. American Journal of Physics, 65(10), 987-996. https://doi.org/10.1119/1.18702. 